\title{
The Migration Response to the Economic Factors: Lessons from Kazakhstan ${ }^{2}$
}

This paper studies the influence of economic conditions in Kazakhstan to the willingness of people to migrate from Kazakhstan to Russia. There were high numbers of people emigrating from Kazakhstan to Russia in $2008(10,365)$ and $2009(11,187)$ due to the economic crisis in 2008. We argue that the lower economic development in Kazakhstan leads to the higher migration of people from Kazakhstan to Russia. Economic data for Kazakhstan and Russia in 2004-2014 periods is examined to establish whether the economic development and net migration are strongly correlated. Net migration is the difference in total number of people leaving the country and coming to the country. A positive net migration occurs when there are more people entering to the country than going out. A negative net migration means that more people are leaving the country than coming in. Moreover, in order to compare results among different social groups, relationship of net migration based on residency (urban and rural) and age categories to the economic indicators is analyzed. It is found out that net migration from Kazakhstan to Russia is highly affected by the economic situation in Kazakhstan, especially by unemployment level in Kazakhstan. Thus, the results indicate that urban residents more tend to move to Russia than rural residents due to It is concluded that economic reasons are significant for retired people. Based on the results of the study, it is assumed that the migration situation will improve when Kazakhstan diversifies economy, invests in small and medium enterprises, and reviews employment policy.

Keywords: migration, Kazakhstan, Russian Federation, economy.

JEL: F22

$1 \quad$ Nurlyaiym Zhaksybayeva - Master in Public Policy, Center for trade policy development under the Ministry of National Economy of Kazakhstan. <E-mail: n.zhaksybayeva@ gmail.com>; Saltanat Nurzhanova - Master in Public Policy, Kazakhstan. <E-mail: saltanatnurzhanova.a@gmail.com>. 


\section{Introduction}

This study addresses the effect of economic factors on migration from Kazakhstan to Russia. The main argument is that the movement of people is closely related to the various economic conditions of the country. We answer the question "How does economic development influence to migration from and Kazakhstan to Russia?" Furthermore, we analyze how the migration has changed from 1990s.

To understand why migration is a crucial issue, we need to acknowledge that the main resource of a country is people. In the globalizing world ideas, information, technology and people move easily. Especially the development of transportation roads, increase in liberalization of trade relations, development of communication tools leads to more intensive migration process.

Migration is "the movement of a person or group of persons from one geographical unit to another across and administrative or political border, and wishing to settle permanently or temporarily in a place other than their place of origin" (IOM, 2003, p.8).

The migration process in the territory of Kazakhstan differs across the time. For instance, in the 90s of 20thcentury the CIS region experienced inter-state migration towards Belarus, Ukraine and Russia. The reasons were the collapse of the Soviet Union, ethnic, political rational and the emergence of independent states in Central Asia. The main flows were Russians from ex-Soviet countries to Russia, especially from Kazakhstan (Zaionchkovskaya, 1996, 2000). In the new millennium the migration process in the post- Soviet countries has started to stabilize and there are no such high patterns like in 1990s and the reasons to migrate have changed significantly.

According to Ravenstein's push and pull factors theory of migration, there are some reasons that dominate in making a decision. For instance, ethnicity, family ties, psychological and emotional effect, legal framework, economic reasons etc.

After independence there was a negative net migration (balance of emigrants and immigrants) from Kazakhstan to other countries. According to the individual choice theory of migration, another push factor of migration is ethnicity (Zelinskiy,1971). The situation can be explained by this theory, and we argue that the willingness of people to migrate to the ethnic origin countries was one of the dominant factors. The nationalities of Slavic origin and German population of Post-Soviet Kazakhstan started returning to their ethnic origin countries (Andrienko and Guriev, 2004). According to the data of Statistics Committee of Kazakhstan in 2014, the top spots in the index of emigration by nationality were occupied by Russians. For instance, the peak of migration was in 1994 , when almost half a million $(477,000)$ people emigrated from Kazakhstan to Russia, and the majority of whom were ethnic Russians (Nurumbetova, 2010). Due to the lack of exact number of people migrating from Kazakhstan to Russia in the context of nationalities in Kazakhstani database, the argument could be checked via data provided by stat.gov.kz for the net migration from Kazakhstan to CIS countries by ethnicities (Fig. 1). Considering that the 
biggest share of emigrants to CIS is migrating to Russia, we assume that it shows trends for Kazakhstan- Russia destination. High negative net is observed among Russians, Belarusians and Germans. Among them, Russians have the highest number of negative net migration. It means that in comparison with other nationalities Russians emigrate most and immigrate less than others. Over the last year this index slipped into -17,000 (Fig. 1). It is worth noting that the dynamics of the net migration demonstrates a various picture over the past five years. So, in 2010 the difference between Russians left and coming into the Republic of Kazakhstan reached $-13,000$, while in 2011 the figure jumped to nearly $-20,000$, and then showed $-18,000$ and $-14,000$ in 2012 and 2013 respectively. It was the highest degree of negative net migration in 2008. It could be again explainable by the global economic crisis.

"Family ties" is another factor that may cause migration, because if there is a family member in a host country, there is a high possibility to migrate to that particular country. Also, the existence of relatives who have already migrated to the destination country facilitates the process of migration (Borjas and Bronars, 1999)

Ravenstein's (1889) neoclassical economy and push and pull factors theory of migration introduces "laws of migration", and one of the seven laws states that key cause of migration are economic factors. According to Ravenstein's theory, migration initiatives are forced by such push factors as poverty, low social status, unemployment, bad political situation etc., and pull factors as job opportunities, high income, political freedom, psychological aspects etc. In the macro level of migration these trends can be explained by unbalanced job distribution, meaning more jobs and higher salary are provided in one country and comparably less opportunities in others (Massey, 1998).

Kazakhstan's and Russia's attempts to overcome negative consequences of the world economic crisis in 2008 have influenced the movement of people between those countries. The main patterns are that low skilled people tend to move from the southern neighbors (Kyrgyzstan, Uzbekistan, Turkmenistan) to Kazakhstan and Russia, whereas, high skilled people migrate from Kazakhstan to Russia or other foreign countries. It is important to understand how economic development influences the migration process, in order to foresee the social, economic, demographic challenges in the future. Also, our research is significant in the current reality, because Kazakhstan is facing economic challenges. GDP growth in 2015 was $1.3 \%{ }^{1}$, and the projection growth by IMF for 2016 is zero ${ }^{2}$. Moreover, the emigration of human resources increases the necessity in workforce. Also, if to take into account

1 Country Overview. (2016, 20 March). URL: <http://www.worldbank.org/en/country/kazakhstan/overview.

2 S↔P в 2016 году не прогнозирует рост ВВП Казахстана. (2016, 14 March). URL: $\quad<$ https://kapital.kz/economic/48599/s-p-v-2016-godu-ne-prognoziruet-rost-vvp-kazahstana.html. 


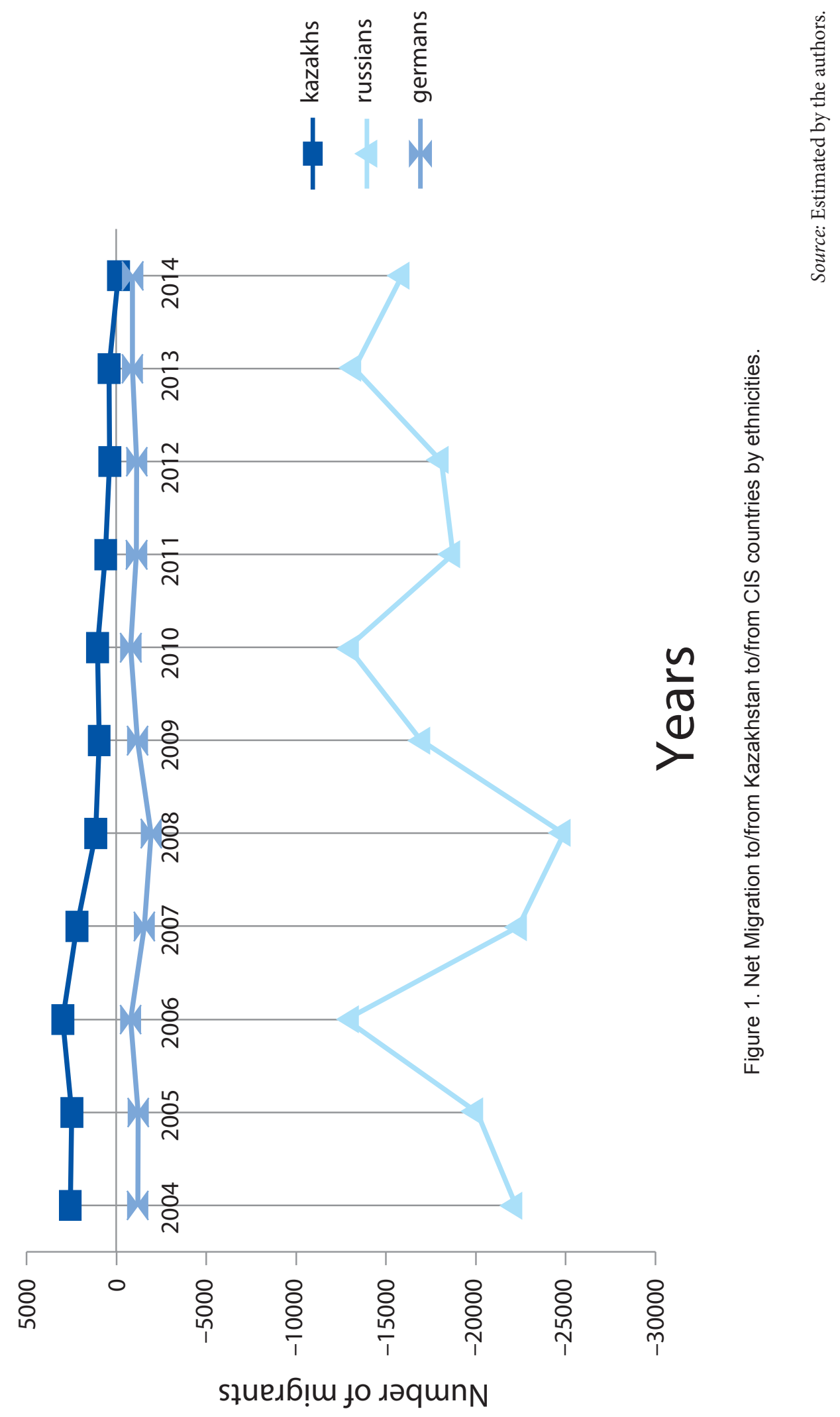


that the vast majority of migrants are professionals with technical and higher education, it is very costly to Kazakhstan. According to Zhatkanbaeva et al. (2012), the cost of emigration of professionals was 125 billion U.S. dollars within 1992-2004. So, because of the above stated reasons, we believe that our research has an importance.

Our research is closely connected with the study done by Becker, Musabek, Seitenova, Urzhumova (2005). Their work is focused on the monthly data in a period from 1995 to 1999. There were several interesting findings, and for instance, the paper argues that the retirement age and working age groups have different responsiveness to the economic issues as unemployment level in Kazakhstan and Russia, real wage rates, real exchange rates, inflation and real capital investment. As the result of the research they find out that retired people are migrating more to Russia from Kazakhstan than people of other age groups. Moreover, their results show that Russian ruble crisis in 1998 has a huge effect on migration. As the result of the paper authors could prove via statistical analysis their assumptions that economic reasons are significant in making the decision to migrate. Having found these kinds of results we are interested in testing such patterns for more recent times, and therefore we focus on 2004-2014 years data.

This paper is organized in a way that it explains the main migration patterns from Kazakhstan to Russia in the past 15 years. The following section Significance of problem argues about the aims to provide arguments why the topic is urgent, and how it could contribute to the previous research done on the topic. The next section called The Model, and it focuses on the assumptions that we present throughout the paper. In this section there were introduced the sources of data used for the research, and methods that were applied.

The section The Results present the outcomes of the regressions. Feasible policy recommendations that are aimed to improve the situation were presented in the section Conclusion and Recommendations. For instance, the improvement of Employment Map 2020 plan, diversification of economy and exchange rate stabilization have been suggested as possible solutions to the problem.

\section{Significance of problem}

Migration topic is broad with different dimensions and could be studied from various perspectives (Mustafayev, 2006). Due to the lack of research on migration in post- independence Kazakhstan our paper contributes to the topic. The studies on migration describe mostly the patterns of the migration in general, but do not focus on the particular receiving countries. Our study considers Kazakhstan-Russia net migration. Moreover, we provide recommendations to prevent it, whereas majority of the study done is descriptive.

According to the United Nations Development Program, Kazakhstan lost over two million people in 1992-2004 as a result of external migration. According to Fig. 
2, the number of people emigrating from Kazakhstan to Russia sharply climbed in $2008(10,365)$ and $2009(11,187)$ respectively. It could be explainable with the Global Economic Crisis in 2008 that damaged the economy of Kazakhstan more intensively than Russian, because Kazakh economy was young, unstable in comparison with the economy of Russia. World financial markets froze up the capital inflows to banks in Kazakhstan that caused a credit crisis in the beginning of 2008. Also the immediate fall of the oil prices lead the economy of Kazakhstan to fall into the recession. That's why it leads to the shutdown of businesses and increase of the unemployment. For comparison, the unemployment rate in Kazakhstan was $7.3 \%$, while in Russia this indicator was $6.4 \%{ }^{1}$. As the result of this economic situation people started moving to Russia in search of a job and higher salaries. But in 2010 Kazakhstan introduced a policy of diversification and economy started recovering from the consequences of economic crisis. As the result of a state programs of combatting crisis in 2010 (8,267 people) and 2011 (4,513 people) we can see steady decrease in the number of migrating people to Russia.

Migration has increased during the transition period to a market economy. It was accompanied by a structural crisis and the liquidation of many manufacturing companies in non-production sphere. "Unemployment", "hopelessness", "no means of subsistence" are the reasons for labor migration referred to the respondents themselves during the interviews conducted in most of the donor countries of CIS by United Nations, Economic and Social Affairs (Ivakhnyuk, 2006). Due to the lack of workplaces, galloping inflation and a sharp drop in the standard of living, people were forced to seek alternative sources of income, including those outside the traditional places of residence and employment. The above stated statistical data shows as economic factors have impact not only to the wellbeing of people, but also to the willingness to stay in their homeland. Thus, it's important to study the impact of economic reasons on migration.

There is a difficulty of forming a common methodology for the study of international migration as a phenomenon of international political reality. Despite a large literature that addresses issues related to both international and regional level migration processes, the topic Kazakhstani migration has not been studied adequately. It is important to consider international experience and develop policies to prevent massive outflow of people. The uniqueness of this work is that the issue of migration has not been researched in complex with economic indicators in Kazakhstan for the last 15 years. The result of the work will be a good base for further research of emigration. This work may raise attention of foreign organizations and research institutions of the Commonwealth of Independent States. Research results and findings can also serve as material for further study of population migration.

1 Trading economics. URL: <http://www.tradingeconomics.com/russia/unemployment-rate. 


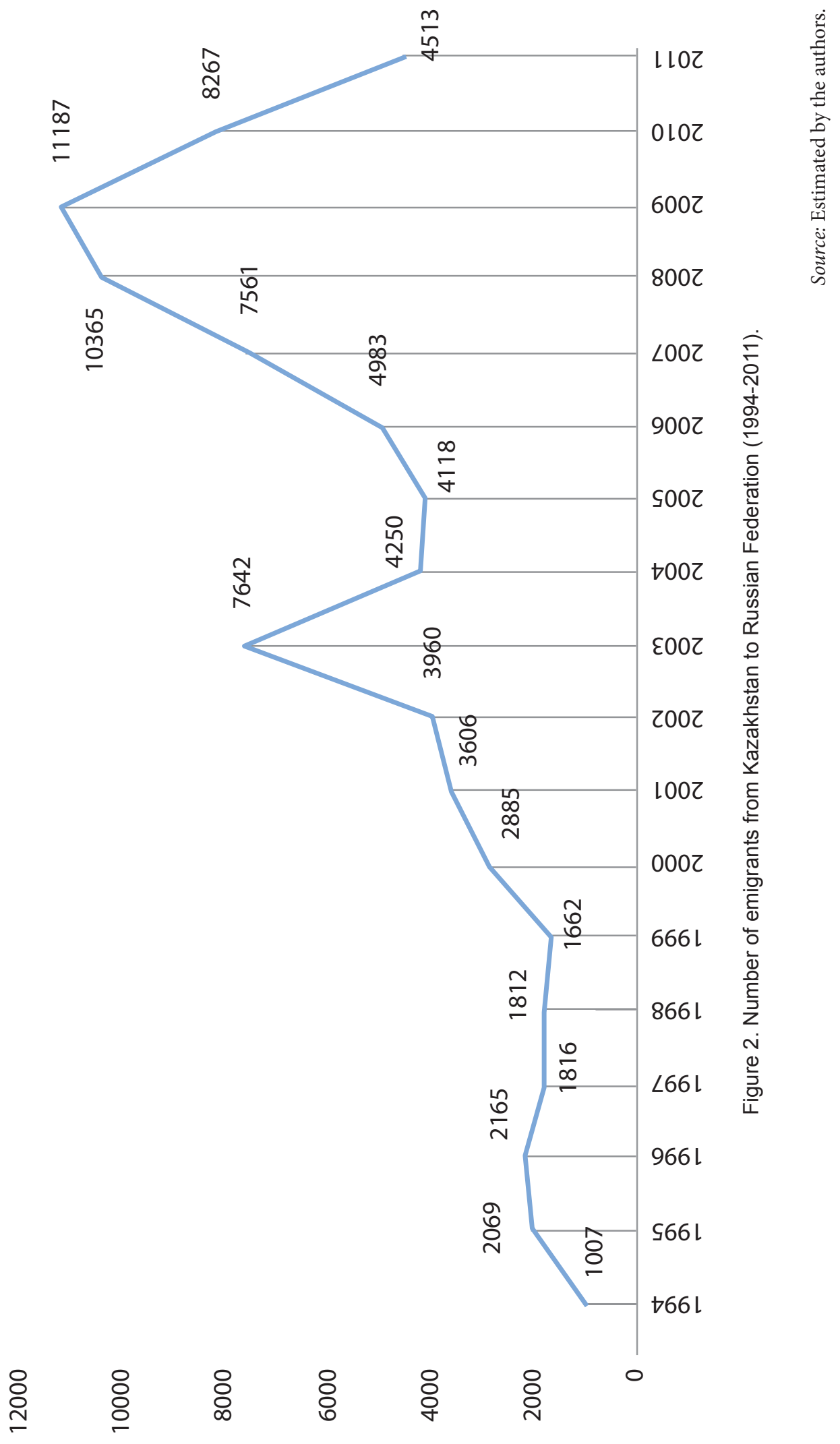


According to Zelinsky's (1971) „hypothesis of the mobility transition', there are 2 categories of migrants: low-skilled and high-skilled. The second needs more attention, because high-qualified professionals have higher productivity and boom the economy. So, one of the aspects, why immigration problems are crucial for the research, is that it may cause outflow of professionals, brain drain problem in the country of origin. The effect of the brain drain is huge for the labor market in the country of origin (Hamada, 1977, p20). It spends a big amount of financial resources in order to educate their people and provide scholarships, build institutions, then as the result of the emigration they lose considerable amount of professionals. For the countries that have less capable human resources keeping them is very important. Taking into consideration a huge damage of an emigration of professionals this research paper contributes to the study of migration of highly qualified citizens and analyzes possible causes.

The emigration of professionals is very harmful for the economy of Kazakhstan. The total damage caused by the brain drain has been calculated according to the method tested in Russia, and it was valued at 125 billion U.S. dollars. It shows that the problem of brain drain is very significant for Kazakhstan (Zhatkanbaeva, 2012). As illustrated by the official figures in Table 1 (Statistical Committee of RK) for three years in categories: "higher education", "incomplete higher education", "secondary special education", the net migration was negative for the "Higher education", "incomplete higher education" and "Secondary special" categories of migrants by levels of education. It means that the number of people emigrating is higher than people coming to the permanent stay from Russia to Kazakhstan. The main directions for those who left Kazakhstan are CIS countries, where there is demand for their skills. Thus migration is detrimental issue to study, and our paper contributes to the following topic by analyzing the reasons of migration. If we can find the reasons of migration, it would be easier to come up with policies to prevent it.

\section{Table 1}

\section{Net migration by education level to/from Kazakhstan to/from CIS}

\begin{tabular}{|l|l|l|l|l|l|l|l|}
\hline & \multicolumn{3}{|l}{ Emigrants } & \multicolumn{2}{l}{ Immigrants } & $\begin{array}{l}\text { Net } \\
\text { migration }\end{array}$ \\
\hline Years & 2009 & 2010 & 2011 & 2009 & 2010 & 2011 & $2009-2011$ \\
\hline Total & 31,282 & 31,775 & 29,832 & 28,273 & 22,448 & 27,082 & 15,086 \\
\hline Higher education & 4,180 & 4,327 & 3,791 & 7,598 & 6,618 & 8,380 & $-10,298$ \\
\hline $\begin{array}{l}\text { Incomplete } \\
\text { higher education }\end{array}$ & 986 & 1,018 & 791 & 1,817 & 1,251 & 1,236 & $-1,509$ \\
\hline $\begin{array}{l}\text { Secondary } \\
\text { special }\end{array}$ & 6,118 & 7,021 & 6,564 & 8,668 & 7,021 & 9,016 & $-5,002$ \\
\hline High school & 15,808 & 15,641 & 15,088 & 7,432 & 5,506 & 6,224 & 27,375 \\
\hline $\begin{array}{l}\text { Incomplete } \\
\text { high school }\end{array}$ & 4,157 & 3,735 & 3,393 & 2,688 & 1,992 & 2,156 & 4,449 \\
\hline Other & 33 & 33 & 205 & 70 & 60 & 70 & 714 \\
\hline
\end{tabular}

Source: Ministry of National Economy of the Republic of Kazakhstan Committee on Statistics. URL http://stat.gov.kz 
In 2008, the President of Kazakhstan called for all scientists who are abroad to return to Kazakhstan, and support the development of domestic science, by promising decent wages, and the ability to do research on the most modern equipment. Some accepted the offer and came back. On the other hand, the initiative was not within the framework of a special state program. It was just an ideological appeal to nation building.

The National Population Program 2011-2020 was introduced by the Government of Republic of Kazakhstan in 2005. It aims to improve demographic situation, to maintain a balance between the immigrants and emigrants within the country. According to this plan, the number of emigrants should not to outnumber the immigrants (Nazarova, 2000). Our research aims to assist in the implementation of the state policies within the framework of this plan. It helps to identify the parts of the program that are not performing well.

Taking into account above mentioned arguments we can conclude that the issue of migration touches different aspects of economy. The migration process is influenced by economic indicators. Our work targets the Government of Republic of Kazakhstan as its main client. The findings of this research and provided recommendations could be a good base for the development of policies on migration.

\section{Model}

According to Heleniak (2003), the push and pull factors of migration from Kazakhstan to Russia are due to the ethnicity. But Becker et al. (2005) find that there are economic reasons to migrate in this direction. We argue that lower level of economic development in Kazakhstan leads to the negative net migration from Kazakhstan to Russia. Net migration is the total number of people who leave the country less the total number of people who move to that country. A positive net migration means that there are more people coming to the country than leaving it, and a negative net migration represents that more people are leaving than entering the country. We focus on the period from 2004 to 2014, because there is a research for the after independence period 1995-1999 (Becker et al, 2005) and when we have started our research, the latest available data was for 2014. Moreover, Zaionchkovskaya (1996) finds that the main cause of migration from Kazakhstan to Russia after the independence was the willingness of people to move back to the ethnic origin countries, and this flow has slowed down in 2000s. The economic growth of Kazakhstan (0.5\% in 1996, 10.7\% in $2006,4.3 \%$ in 2014) has improved the conditions in the country, and migration reasons have changed ${ }^{1}$.

1 Index mundi. URL: <http://www.indexmundi.com/kazakhstan/gdp_real_growth_ rate.html. 
In this work we analyze that lower economic development in Kazakhstan leads to the higher willingness to migrate from Kazakhstan to Russia. We regress net migration from Kazakhstan to Russia on unemployment level in Kazakhstan, controlling for unemployment level in Russia, real exchange rate tenge/ruble, real wage rate, real capital investment in Russia, real capital investment in Kazakhstan, inflation rate in Russia. The data on net migration from Kazakhstan to Russia, real wage rate in Kazakhstan, real capital investment in Kazakhstan are taken from the official website of the Ministry of National Economy of the Republic of Kazakhstan Committee on Statistics (Statistics Committee) website. The data on real wage rate in Russia, real capital investment in Russia are retrieved from Russian Federation Federal State Statistics Service (Russian Statistics Service) website. The unemployment level in Kazakhstan and Russia, inflation rate in Russia are from the website of the World Bank. The exchange rate tenge/ruble is from the website of Kazfin.

We are looking at the relationship of unemployment level in Kazakhstan to the net migration from Kazakhstan to Russia. The independent variable is unemployment level in Kazakhstan. We estimate the negative relationship with the dependent variable: higher the unemployment level in Kazakhstan is, the net migration from Kazakhstan to Russia will be negative (people are more willing to migrate from Kazakhstan to Russia).

We use control variables in order to analyze properly our main hypothesis. By regressing unemployment level in Russia as the control variable we expect that higher the unemployment level in Russia is, lower the willingness of people to migrate from Kazakhstan to Russia will be.

With real exchange rate tenge/ruble we estimate that people's decision to migrate is influenced by the exchange rate, because they would like to have better quality of life and compare prices in both countries.

According to neo-classical economic theory, labor migration is possible due to the wage differences between countries. Those international labor flows create a new equilibrium, and real wages are the same in all countries at that point (Borjas, 1989; Massey et al., 1993, 1998; Bauer and Zimmermann, 1995, Oeberg, 1997). The other control variable is real wage rate. We expect that higher the real wage rate is, higher the willingness to migrate from Kazakhstan to Russia will be. We use the formula from Becker et al. paper (2005), in order to have the ratio of real earnings for both countries:

$$
\begin{gathered}
R R E=W_{r u s} / P_{r u s} \times E W_{r u s} \times Q, \\
W_{k a z} / P_{k a z} \times W_{k a z}
\end{gathered}
$$

$W_{\text {rus }}$ - the average nominal wage in Russia, $P_{r u s}-$ the consumer price index in Russia, $W_{k a z}$ - the average nominal wage in Kazakhstan, $P_{k a z}-$ the consumer price index in Kazakhstan, $E$ - the exchange rate, the number of Kazakhstani tenge per Russian ruble, $Q$ - the real exchange rate. 
We take real capital investment in Russia and real capital investment in Kazakhstan as the control variables. The capital investment per employee might influence to the increase in wage and employment in future, and affect to the expectations of people who are willing to migrate. We estimate that higher the real capital investment in Russia is, higher the willingness to migrate from Kazakhstan to Russia will be; higher the real capital investment in Kazakhstan is, lower the willingness to migrate from Kazakhstan to Russia will be.

The next control variable is inflation rate in Russia. We expect that higher the inflation in Russia is, lower the willingness to migrate from Kazakhstan to Russia will be.

According to Becker et al. (2005), the specific social groups' migration has different patterns. Furthermore, we analyze the specific social groups' responsiveness to the unemployment level in Kazakhstan and other economic variables. We change the dependent variable to net migration of Russian ethnicity from Kazakhstan to Russia, net migration of German ethnicity from Kazakhstan to Russia, net migration of urban residents from Kazakhstan to CIS, net migration of rural residents from Kazakhstan to CIS, net migration of three different age groups from Kazakhstan to CIS. All the data is taken from the Statistics Committee website. The data of net migration for urban, rural, and age categories are from Kazakhstan to CIS countries, but we assume that the migration is predominantly to Russia specifically (in 2014 82\% of total migrants to CIS countries migrated from Kazakhstan to Russia) ${ }^{1}$.

According to Heleniak (2003), the movement of Russian and German ethnicity representatives from Kazakhstan was due to the ethnicity reasons and willingness to move back to the origin countries after the collapse of the USSR. We analyze if those variables are responsive to the economic reasons. We expect that the higher level of unemployment in Kazakhstan is, higher the willingness of Russian and German ethnicity representatives to migrate from Kazakhstan to Russia will be.

Thus, we analyze the migration of urban and rural residents from Kazakhstan to Russia due to the economic reasons. We expect that higher the unemployment level in Kazakhstan is, higher the willingness of urban residents to migrate from Kazakhstan to Russia will be. According to Zelinskiy (1971), internal migration is higher from rural places to urban, whereas, international migration takes place mostly by urban residents. We assume that the urban residents are more willing to migrate from Kazakhstan to Russia than rural residents, because if the rural resident is not satisfied with current life conditions, she/he is more willing to migrate to Kazakhstan's cities, rather than abroad. On the contrary, urban residents who want to migrate have a choice to move to other Kazakhstan's cities or abroad, in our case to Russia.

1 В какие страны эмигрируют Казахстаниьы? (2015, 4 December). URL: <http:// www.kursiv.kz/news/top_ratings/v-kakie-strany-emigriruut-kazahstancy/. 
When we analyze the migration from Kazakhstan to Russia for different age groups, we divide the age for three categories. First age group is 6-17 years old, second age group is 17-62 (57) years old, and third age group is 63 (58)+ years old. As we can notice from Fig. 4, children from 6-17 years is less migrating rather than adults. Migration indicators are higher in the second group rather than people older than 63. The net migration data of the first and second groups show similar patterns due to the assumption that children follow their adult parents, and it is flexible. However, the third group's net migration data is more stable. We expect that three age groups are responsive to the different economic variables, and retired people (the third group) are estimated the less significant results. The estimations are that higher the unemployment level in Kazakhstan, higher the willingness of the adult people to migrate from Kazakhstan, and children should follow adults; whereas, the economic reasons are not significant for retired people.

\section{Regression results}

Becker et al. (2005) argue that the migration from Kazakhstan to Russia is responsive to the economic situation. They regress net migration rate of two countries on economic shocks. Becker et al. (2005) concentrate on six categories of variables. First, they analyze the influence of difference of current and past periods' values of dependent variables to the current growth rates. Second, according to Heleniak (1999) and Andrienko and Guriev (2004), people of working age are motivated to migrate by changes in the labor market, like relative wage rates and unemployment. Third, investment per worker might positively affect to future wage and employment growth. Fourth, the retirement age people tend to move due to family reasons and similar pension policies in both countries. Fifth, there is a relationship of exchange rate by the willingness to migrate. Finally, the economic news like economic crisis (Russian crisis in 1998) might influence to the decision to move. Becker et al. (2005) find that net migration of working age people is influenced by changes in opportunities and expected earnings. Whereas, changes in exchange rates influence to migration immediately and effect is in a minimal period. Moreover, the Russian crisis variable shows the reduction in emigration from Kazakhstan to Russia. The retired people are willing to migrate due to strong inter-generational ties. Therefore, the elderly people move if their children make decision to migrate.

We use the similar model, but argue that lower the economic development of Kazakhstan is, higher the willingness to migrate from Kazakhstan to Russia. We analyze net migration from Kazakhstan to Russia on unemployment level in Kazakhstan, controlling for unemployment level in Russia, real exchange rate tenge/ ruble, real wage rate, real capital investment in Russia, real capital investment in Kazakhstan, inflation rate in Russia.Net migration is the total number of people leaving the country less the total number of people arriving to that country. A positive net migration is that there are more people coming to the country than leaving it, and a negative net migration means that more people are leaving than moving to the country. 


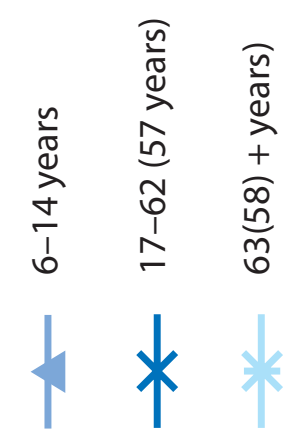

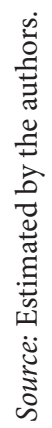

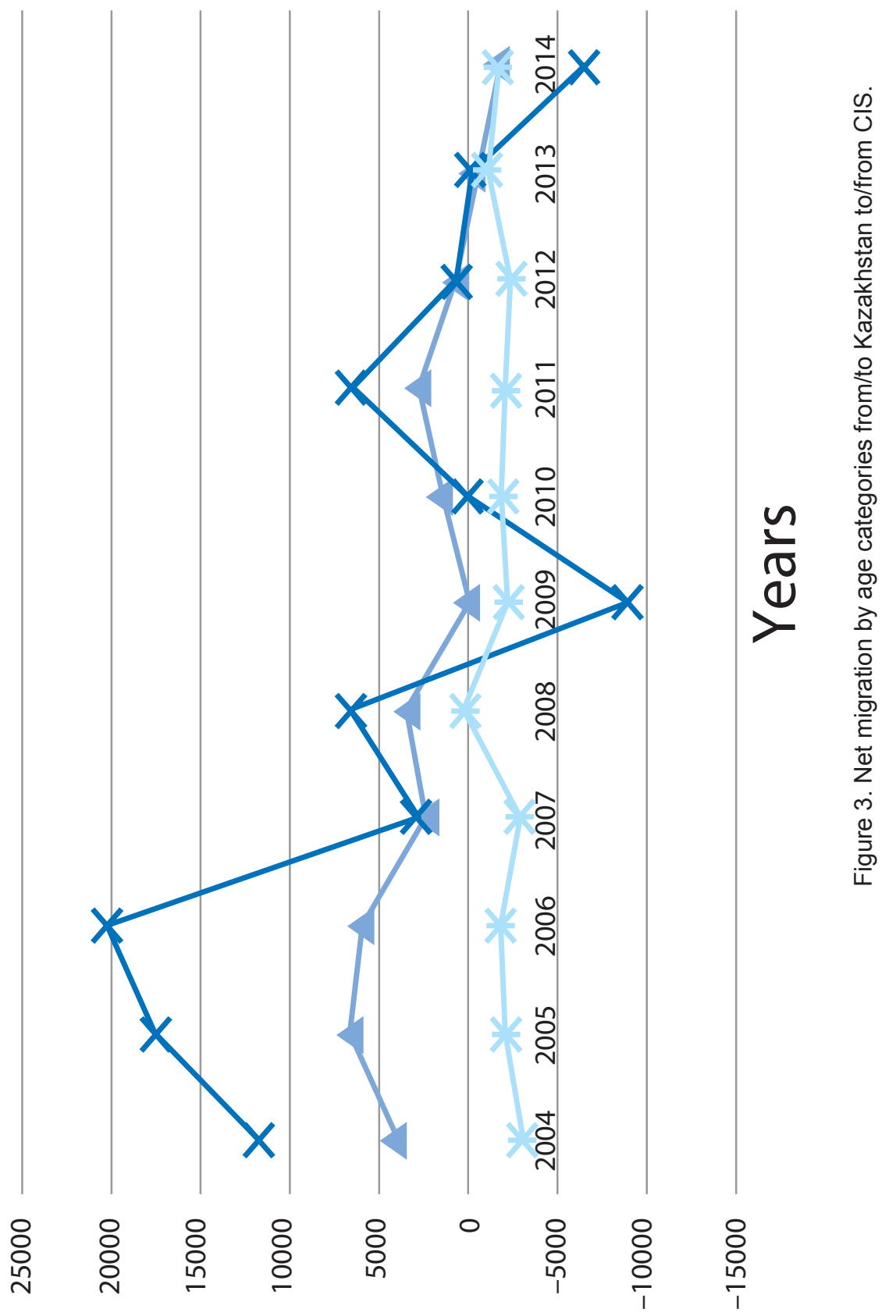


We expect that the higher unemployment level in Kazakhstan leads to the increase in people's willingness to migrate from Kazakhstan to Russia. We assume that people are willing to move to the country with higher wage rates. We estimate that people migrate more often when the real capital investment is higher in the destination country. Thus, due to the high inflation rate in Russia people might make decision to stay in Kazakhstan.

The regression results are indicated in Table 2. The variables for unemployment, real wage rate, real capital investment and inflation are insignificant for the current year, but they are statistically significant for the previous year (Lag 1). When we run regression using unemployment data for previous two years (Lag 2), it was not significant. On the other hand, the real exchange rate is statistically significant for the current year, not previous.

We did not estimate in the beginning that the previous year (lag) variables would be significant. But it is rational that migrants are interested in the conditions in destination countries. When someone is willing to move from one place to other, the person tends to expect better life. The migrants look at the previous year's chances to get jobs, compare salaries and prices of two countries, but they look to the real time's exchange rate in order to estimate options.

Thus, the signs and relationships are as we have estimated before running the regression. The more level of unemployment in Kazakhstan, the net migration is decreasing and more people are willing to migrate to Russia. We estimate that the exchange rate of the previous year might influence to the decision to migrate, but the regression shows that it is statistically insignificant. Real capital investment per worker shows the positive relationship with the dependent variable. People are more willing to migrate if there is smaller real capital investment in Kazakhstan. Inflations for the current and previous years are statistically insignificant, and such results are unexpected. The possible reason is that people who are willing to migrate consider the real wage rate, which is adjusted to the inflation. Also migrants may look to the consumer basket, but not to the inflation level.

To sum up, the pull factor is better economic conditions in the destination country. For example, the economy of Kazakhstan has been improved from 2004 to 2014. The GDP growth of Kazakhstan was at peak in 2006 (10.7\%), during the 2008 crisis it has decreased to $3.3 \%$ (2008) and $1.2 \%(2009)^{1}$. But the anti-crisis policies (stabilization of financial sector, solution of the housing market problems, investing in SME, agriculture, industrialization and infrastructure) were successful, and in 2010 the economy recovered with the growth $7.3 \%$. On the other hand, the Russian economic growth was at peak in 2007 (8.5\%), and after the $2008 \mathrm{cri}$

1 Index mundi. URL: $<$ http://www.indexmundi.com/kazakhstan/gdp_real_growth_ rate.html. 
Table 2

\section{Regression results ${ }^{1}$}

\begin{tabular}{|c|c|c|c|c|c|c|c|}
\hline \multirow{2}{*}{$\begin{array}{l}\text { Y } \\
\text { Constant }\end{array}$} & \multicolumn{4}{|c|}{ Net migration } & \multirow{2}{*}{$\begin{array}{l}\begin{array}{l}\text { Net mig } \\
\text { Russians }\end{array} \\
5,03 \\
(-14,64)\end{array}$} & \multirow{2}{*}{$\begin{array}{l}\begin{array}{l}\text { Net mig } \\
\text { Germans }\end{array} \\
0,41 \\
(25,40)\end{array}$} & \multirow{2}{*}{$\begin{array}{l}\begin{array}{l}\text { Net } \\
\text { migration }\end{array} \\
7,13 \\
(46,95)\end{array}$} \\
\hline & $\begin{array}{l}5,05 \\
(3,73) \mathrm{s}\end{array}$ & $\begin{array}{l}5,58 \\
(4,12)\end{array}$ & $\begin{array}{l}3,58 \\
(3,10)\end{array}$ & $\begin{array}{l}6,87^{\star 9} \\
(44,81)\end{array}$ & & & \\
\hline $\begin{array}{l}\text { Unemploy- } \\
\text { ment in Russia } \\
\text { (L1) }\end{array}$ & & & & $\begin{array}{l}-0,68^{*} \\
(-20,901\end{array}$ & $\begin{array}{l}-0,47 \\
(-8,901\end{array}$ & $\begin{array}{l}-0,0045 \\
(-12,951\end{array}$ & $\begin{array}{l}-0,74 \\
(-23,43)\end{array}$ \\
\hline $\begin{array}{l}\text { Unemploy- } \\
\text { ment in } \\
\text { Kazakhstan (LI) }\end{array}$ & $\begin{array}{l}-0,1 \\
(-3,78)\end{array}$ & $\begin{array}{l}-0,11 \\
\mathrm{H}-14)\end{array}$ & $\begin{array}{l}-0,065 \\
(-2,71)\end{array}$ & $\begin{array}{l}-0,18^{*} \\
(-32,95)\end{array}$ & $\begin{array}{l}-0,13 \\
(-1464)\end{array}$ & $\begin{array}{l}-0,014 \\
(-23,64)\end{array}$ & $\begin{array}{l}-0,19 \\
(-55,21)\end{array}$ \\
\hline Real wage rate & $-1,67$ & $-2,19$ & $-1,004$ & $-1,11^{*}$ & $-1,36$ & & \\
\hline (L1) & $(-4,06)$ & $(-3,78)$ & $(-2,41)$ & $(-31,101)$ & $(-14,33)$ & & \\
\hline Real wage rate & $-0,84$ & $-0,88$ & $-0,95$ & $-0,79^{*}$ & -0596 & $-0,09$ & $-1,94$ \\
\hline (L2) & $(3,02)$ & $(-3,32)$ & $(4,72)$ & $(-20,52)$ & $(-9,47)$ & $(-14,72)$ & $(-26,69)$ \\
\hline Real exchange & $-0,31$ & $-0,37$ & $-0,197$ & $-0,33^{*}$ & & $-0,039$ & $-0,74$ \\
\hline rate & $(-3,77)$ & $(-4,05)$ & $(-2,52)$ & $(-31,97)$ & & $(-9,54)$ & $(-23,24)$ \\
\hline Real exchange & & 0,11 & & & & $-0,017$ & $-0,34$ \\
\hline rate $(\mathrm{L} 1)$ & & $(1,21)$ & & & & $(-16,05)$ & $(-35,58)$ \\
\hline Real capital & & & & $-3,06^{*}$ & $-1,96$ & $-0,28$ & $-3,17$ \\
\hline investment (L1) & & & & $(-12,90)$ & $(-5,06)$ & $(-11,08)$ & $(-22,48)$ \\
\hline Inflation (L1) & & & & & & & $\begin{array}{l}0,0001 \\
(2,31)\end{array}$ \\
\hline $\mathrm{R} 2$ & 0,8220 & 0,8802 & 0,9339 & 0,9825 & 0,9967 & 0,9962 & 0,9999 \\
\hline Adj R2 & 0,6440 & 0,6806 & 0,8238 & 0,9301 & 0,9868 & 0,9930 & 0,9991 \\
\hline Durbin-Watson & 1,015443 & 1,230407 & 1,600137 & 1,614291 & 2,615093 & 2,615093 & \\
\hline d-statistics & (reject) & (reject) & $\begin{array}{l}\text { (incon- } \\
\text { clusive) }\end{array}$ & $\begin{array}{l}\text { (incon- } \\
\text { clusive) }\end{array}$ & $\begin{array}{l}\text { (fail to } \\
\text { reject) }\end{array}$ & $\begin{array}{l}\text { (fail to } \\
\text { reject) } 10\end{array}$ & \\
\hline
\end{tabular}

Source: Estimated by the authors.

$1 \quad$ Coefficients are in hundred thousand: $t$-statistics is in parenthesis, ${ }^{*} p<0.05$. We assume that residuals from different regressions could be correlated due to a period with a positive residual for net migration as total is likely to have a positive residual for other different ethnic groups. Langrangemultipler (LM) tests of heteroskedasticity give us the results to reject the hypothesis of homoskedasticity, according to Breusch and Pagan (1980). The results of Durbin Watson statistics illustrate different results. When finding $d$-statistics is less than $d L=1.59$, we reject the null hypothesis, and conclude that there does exist positive first order autocorrelation. When $d$-statistics of regressions more than $d U=1.76$, we fail to reject the null hypothesis, which means that we have no evidence of significant autocorrelation. In the cases where Durbin-Watson statistics is between $d L=1.59$ and $d U=1.76$, we are inconclusive, neither rejecting nor failing to reject the null hypothesis. Moreover, we should ensure that our results are not pretended, we have to test for nonstationarity. The standard method to test is the Dickey-Fuller test. We look to the p-value in comparison to the significance level $\alpha=0.05$. Our computed values are lower than the significance level, and we should reject the null hypothesis, which is (HO) there is a unit root for the series. We accept HA that there is no unit root for the series. The series is stationary. 
sis it decreased to $-7.8 \%$ (2009), but recovered in 2010 with $4.5 \%$ growth ${ }^{1}$. We conclude that people are less willing to move from Kazakhstan to Russia if the economic situation is better in Kazakhstan than in Russia.

We argue that the lower economic development of Kazakhstan leads to the higher willingness of people to migrate from Kazakhstan to Russia. We also assume that the migration

patterns might be different by ages of people, and among urban and rural residents. In the regression we use data of net migration by our social groups from Kazakhstan to CIS due to the limits of database. The assumption is that migrants predominantly move to specifically Russia among CIS countries (in 2014 82\% of total migrants to CIS countries migrated from Kazakhstan to Russia) ${ }^{2}$.

We find that net migration among urban residents is responsive to the economic variables. The level of unemployment in Kazakhstan for the previous year, the control variables like the level of unemployment in Russia for the previous year, real wage rate for the previous year, real exchange rate for the previous year are significant for urban residents. People tend to look for the conditions in the destination place, and compare with the current situation in the origin country. The rural residents show the similar results. But the main difference between urban and rural residents is the results on the unemployment level in Kazakhstan in the current year. When we regress net migration among urban residents on the unemployment level in Kazakhstan, the result is statistically significant. But when we analyze net migration.

Among rural residents on the unemployment level in Kazakhstan, the finding is not statistically significant. We assume that it is due to the difference in life styles in urban and rural areas. If a person is officially unemployed in rural area, she/he might be self-employed and work in own agriculture fields. As a result, rural resident might decide to move due to the long term unemployment, and the finding proves it by showing the statistical significance for the previous year unemployment level in Kazakhstan. To sum up, when there is unemployment in the current period, urban residents tend to move from Kazakhstan to Russia in order to find better work places. On the other hand, rural residents migrate when they are not able to find jobs for a long time. Moreover, rural residents make decision to move to cities in Kazakhstan rather to the other country (Aldashev, Dietz, 2011).

Furthermore, we were surprised that patterns of net migration among rural and urban residents were similar. However, net migration among urban residents is

1 Index mundi. URL: $<$ http://www.indexmundi.com/russia/gdp_real_growth_rate.html>.

2 Index mundi. URL: <http://www.kursiv.kz/news/top_ratings/v-kakie-strany-emigriruut-kazahstancy/>. 


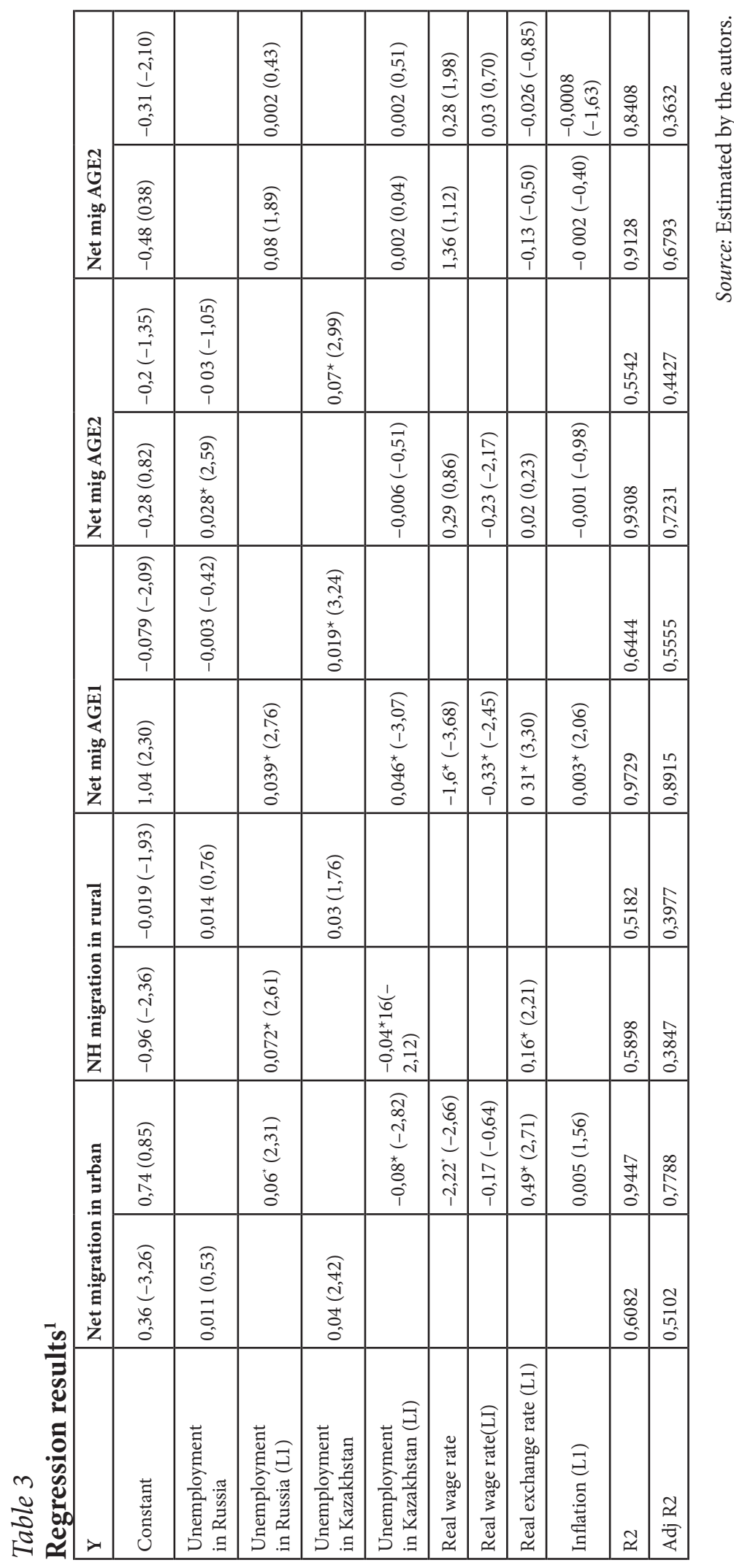

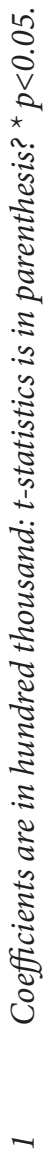


statistically stronger than net migration among rural residents due to the sample size. As the urban-rural movements patterns show, people from the big cities are more willing to emigrate than residents of rural places. According to Fig. 4, urban population shows higher net migration trends, which means that number of urban people moving are higher than the number of rural people moving.

According to the age groups, net migration in the first age group (7-17 years) shows the same results as net migration in the second age group (18-62(57) years). We argue that children (first age group) follow their parents (second age group). We find that higher the unemployment level in Kazakhstan is, higher the willingness of people from 7 to 62(57) years old to migrate from Kazakhstan to Russia will be.

On the other hand, the third age group (63(58)+ years) shows the statistically insignificant results. We assume that retired people's reason to move is not related to the economic conditions, because they might get pensions in Russia as well. According to the bilateral agreement between Kazakhstan and Russia, the person should have a work experience from 1992, and despite of the working country, she/he has a right to receive pension in one of two countries ${ }^{1}$. Longino and Bradley (2003) find that the retirement age people are more willing to migrate to the places with better quality of life. But we argue that retired people have willingness to live in the same city with their children (Becker et al., 2005). They might be helpful in raising grandchildren and reducing the costs for kindergartens, etc.

To sum up, we find that the higher unemployment level in Kazakhstan leads to the higher willingness to migrate from Kazakhstan to Russia. The economic situation in a country is important for making the decision to migrate. People tend to move to the place with better life conditions. However, when we analyze by specific groups based on residency and age, we find different patterns. We argue that urban and rural residents show similar results, but urban residents' case is stronger due to the higher sample size. Furthermore, we find that children follow adults (parents), and they are responsive to the economic conditions. Whereas retired people's result is not statistically significant, and their push and pull factors are not related to economic reasons.

\section{Conclusion and Recommendations}

Overall, the results of this research are similar to the findings of Becker et al. (2005), and the empirical analyze shows that the economic situations in Kazakhstan affect to the migration of people from Kazakhstan to Russia. We find that the movement

1 Муминов А. (2015, 10 April). Пенсия, прощай! Стариков, переехавших из РК в РФ, хотят лишить заработанного годами. URL: <http://www.kursiv.kz/news/vlast/ pensiya_proshchay_starikov_pereekhavshikh_iz_kazakhstana_v_rossiyu_khotyat_lishit_ zarabotannogo_goda_491/. 


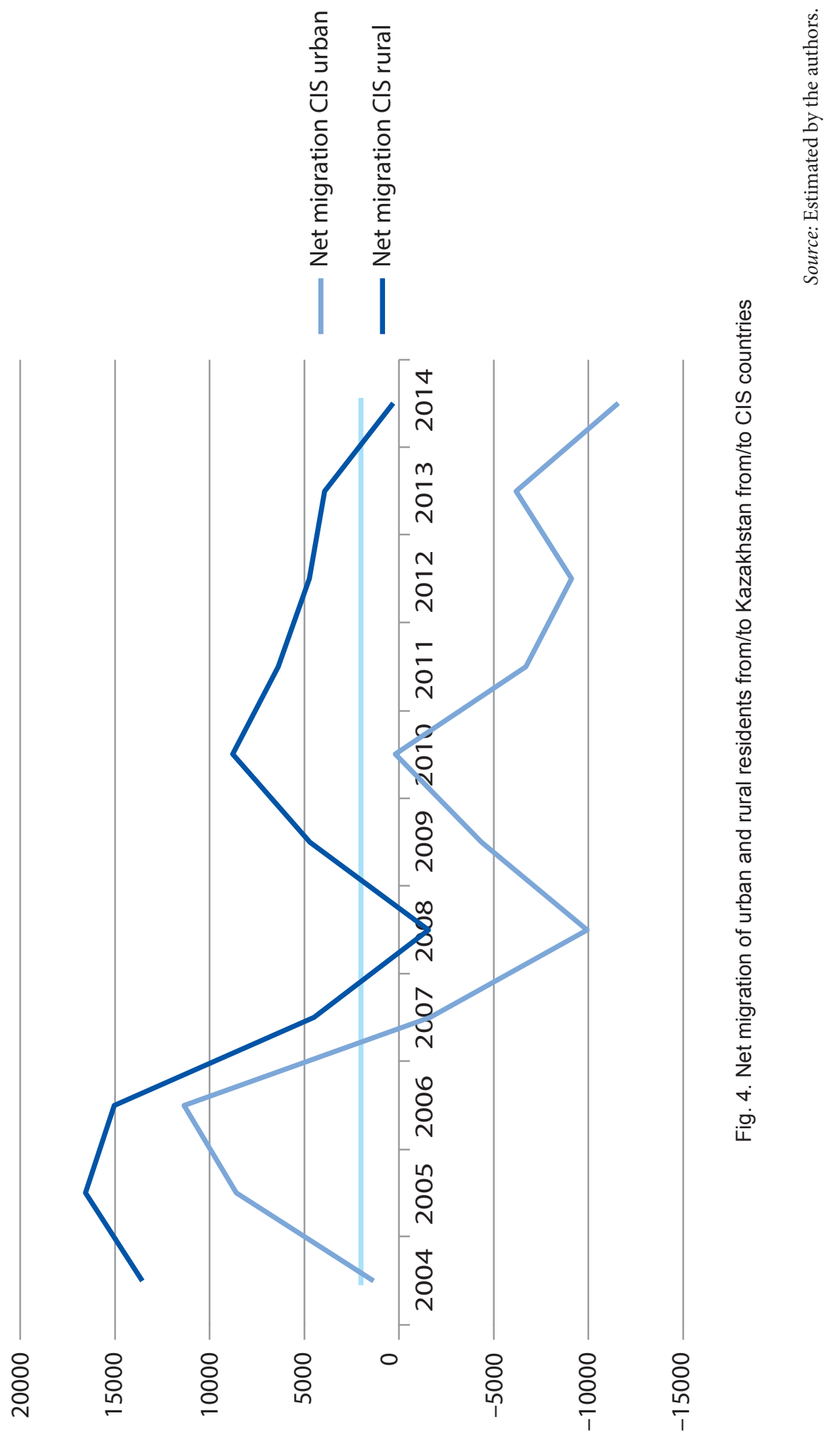


of people from Kazakhstan to Russia is influenced by the unemployment level in Kazakhstan. The push factor of migration from Kazakhstan to Russia is the difficulties in finding jobs.

Interestingly, the regression of net migration from Kazakhstan to Russia on economic variables was statistically insignificant for the current year indicators, but it was significant for the previous year data. We explain this as potential migrants consider the previous year economic patterns to make a decision. However, we observe that the exchange rate data is only important for the current year.

Furthermore, we assume that various social groups react differently to the economic situation. We analyze the effect of economic factors in Kazakhstan to net migration of urban and rural residents, and different age groups. The results of net migration of urban and rural residents were similar; they are motivated by better economic conditions. But due to bigger sample size net migration of urban residents is strongly significant. According to the age groups, children follow adults (parents), and retired people are not motivated by economic indicators.

We argue that lower the economic development of Kazakhstan is, higher the willingness to migrate from Kazakhstan to Russia. Due to the finding that the unemployment is a push factor of migration, there is a need to focus on diminishing the level of unemployment. There are several programs that are targeted to deal with this problem. We consider the following policies for creating new work places:

- Population employment program - 2020;

- Further development of Small and medium enterprises (SME).

Population employment program - 2020 has been introduced in 2015 with the initiative of the government of Kazakhstan. The program goals are increasing the level of employment, promoting welfare improvement, and reducing unemployment. The target is that the unemployment rate will not exceed $5 \%$ up to 2020 in Kazakhstan. The program has two steps. It is efficient, and according to the results of the fourth quarter of 2014, the unemployment level decreased for $0.8 \%$ in comparison with 2010.

Despite the positive effects of the program, there is a need for proper monitoring system. The program evaluates underemployed and self-employed people, and seasonal workers as successful cases. However, these groups have no pension insurance, and they are out of the work during non-seasons. But the sustainable goal of the program should be to provide long-term employment.

As our research indicates, by improving Population Employment - 2020 program we increase the number of work places, and decrease the willingness of people to migrate from Kazakhstan to Russia.

Thus, small and medium businesses are one of the factors of economic growth. The role of small and medium-sized businesses is indispensable in solving the 
most pressing economic and social problems, including unemployment. The more government will increase the instruments of business support, higher will be the level of employment (Mamyrov et al., 2002). We recommend government to reduce red tape bureaucracy during the registration and shutting down of the business. Moreover, there should be business supportive policies as reduction of taxes, attractive loans, and affordable business consulting for potential entrepreneurs. Small and medium enterprisers' development will raise the employment and develop the economy, which motivate people to stay in Kazakhstan.

We find that the economic development is important factor to motivate people to stay in the country. Kazakhstan's economy is based on the oil and gas revenue. In order to avoid the "Dutch curse", there should be diversification of economy from crude oil and gas industry. The dominance of primary industries in the structure of the economy leads to the instability of economic growth and long-term stagnation. Therefore, purposeful state policy of diversification and modernization of the economy has a strategic importance for Kazakhstan. The diversification policy positively influences to the increase of competitiveness, and changes raw material orientation of the economy. It improves sustainable economic growth of the country and individual regions. The diversification of economy has an impact to slowing down the migration from Kazakhstan to Russia by developing new sectors of economy, creating new jobs, decreasing unemployment, and in overall, to upgrade the life conditions in Kazakhstan (Rakhmatullina, 2012).

Furthermore, there should be public consultation and public debate about the migration process. For example, in Germany government's commission on migration and integration challenged dominant ideas, and made major changes in thinking and policy (Suessmuth, 2001). The actions should not be in the high level. But sometimes officially commissioned studies (the economics of migration) might significantly influence to policy formation (Glover et al., 2001; Smith and Edmonston, 1997).

To conclude, due to the findings of research we recommend creating new work places by improving Population employment program - 2020, and supporting small and medium businesses; diversifying the economy; and increasing public awareness towards migration.

Going forward, further analyses of migration response to the economic factors might be wise to consider the influence of the Customs Union and the Eurasian Economic Union. Thus, this work uses yearly data, but the results can be replicated with monthly data. We take the data from the Statistical Committee of Kazakhstan, but it might be done by using data from the Russian sources.

To sum up, this study contributes to the previous research on migration process in Kazakhstan by focusing on the economic factors, and provides with feasible recommendations to the government to decrease the outflow of people from $\mathrm{Ka}$ zakhstan to Russia. 


\section{References}

[1] Aldashev A., Dietz B. (2011) Determinants of internal migration in Kazakhstan. URL: <http://www.econstor.eu/handle/10419/57805>.

[2] Andrienko Y., Guriyev S. (2006) Designing of internal and external model of transition for population of Russian Federation. P. 12-53.

[3] Bauer T., Zimmermann KF. (1995) Modelling international migration: economic and econometric issues. URL: <http://www.popline.org/node/306122>.

[4] Becker C.M, Erbolat N., Musabek A. Seitenova D. Urzhumova D. (2005) The migration response to economic shock: lessons from Kazakhstan. P. 2-26. URL: <http://down.cenet.org.cn/upfile/182/200579195252136.pdf>.

[5] Borjas G. Bronars (1999) The economic analysis of migration. P. 16-19. Retrieved from. URL: <http://www.ppge.ufrgs.br/giacomo/arquivos/eco02268/ borjas-1999.pdf $>$.

[6] Edmonston B., Smith J (1997) Economic, Demographic, and Fiscal Effects of Immigration. P. 310-321.

[7] Glover S. (2001) Migration: An Economic and Social Analysis. P. 3-26.

[8] Hamada K, Bhagwati J.N. (1974) The brain drain, international integration of markets for professionals and unemployment, Journal of Development Economics. P. 19-42.

[9] Heleniak T. (2003) The 2002 Census in Russia: Preliminary results. URL: <http://www.tandfonline.com/doi/abs/10.2747/1538-7216.44.6.430\#. VyNYQ9KLRdg>.

[10] Ivanyuk I.V. (2006) International labor migration. P. 47-66.

[11] Longino C.F., Bradley D.E. (2003) A first look at retirement migration trends in 2000. URL: <https://gerontologist.oxfordjournals.org/content/43/6/904.full >.

[12] Mamyrov N.K. (2002) State regulation in the conditions of Kazakhstan. P. 24-28.

[13] Massey D.S., Arango J., Hugo G., Kouaouci A., Pellegrino A., Taylor J.E. (1993) Theories of international migration. URL: <http://www.jstor.org/stable/2938462?seq=1\#page_scan_tab_contents $>$.

[14] Massey D.S. (1999) The international migration at the dawn of the twenty first century: the role of the state. 25. P. 303-327 URL: <http://www.mi- 
grationpolicycentre.eu/docs/SummerSchool2013/readings/Weinar_Rea ding.pdf $>$.

[15] Mustafayev E.N (2006) Migration process in Kazakhstan. P. 101-107.

[16] Nazarova E.V (2000) Foreign labor force in Russia: trends and consequences. P. 91-97.

[17] Nurumbetova K.K. (2010) Migration of Kazakh population in the beginning of 90 s. P. $14-16$.

[18] Oeberg S. (1997) Theories of inter-regional migration: overview. URL: $<$ http://www.diva-portal.org/smash/record.jsf?pid=diva2\%3 A57973\&dswid=1883>.

[19] Organization of international migration report (2003). P. 4. URL: <http:// publications.iom.int/system/files/pdf/wmr_2003.pdf $>$.

[20] Rakhmatullina G. (2012) Diversification of economy of Kazakhstan. P. 1-9. URL: <http://www.kazenergy.com/ru/4-54-2012/6579-2012-10-08-10-0128.pdf $>$.

[21] Ravenstein E.G. (1889) The laws of migration. Pp. 167-235. URL: <https:// cla.umn.edu/sites/cla.umn.edu/files/the_laws_of_migration.pdf $>$.

[22] Suessmuth $R$. The future of migration and integration policy in Germany. 2001. P. 16-23.

[23] Zaionchkovskaya Zh.A. (1996) Migration patterns in the former Soviet Union. P. 15-48.

[24] Zelinsky W. (1971) The hypothesis of human transition. Pp. 219-249. URL: $<$ http://demografi.bps.go.id/phpFileTree/bahan/kumpulan_tugas_mobilitas_pak_chotib/ Kelompok_10/Referensi_paper/Zelinsky_1971_The_Hypothesis_of_The_Mobility_Transition.pdf $>$.

[25] Zhatkanbayev E.B., Zhatkanbayeva J.K. (2012) The Impact of Globalization on "Brain Drain” In Developing Countries. P. 25-46. 


\section{Ответ миграции на экономические бакторы (на примере Казахстана)}

В данной статье рассматривается влияние экономических условий в Казахстане на желание людей мигрировать из Казахстана в Россию. В 2008 году большое количество людей эмигрировало из Казахстана в Россию (10 365) и 2009 году (1 1 187) ввиду экономического кризиса 2008 года. Утверждается, что более низкое экономическое развитие в Казахстане ведет к увеличению миграции людей из Казахстана в Россию. В статье изучаются экономические данные Казахстана и России за период 2004-2014 гг., чтобы выяснить, насколько сильно коррелируют экономическое развитие и сальдо миграция. Сальдо миграции - это разница в общем количестве людей, покидающих страну и прибывающих в страну. Положительное сальдо миграции происходит, когда в страну въезжает больше людей, чем выезжает. Отрицательное сальдо миграции означает, что больше людей покидают страну, чем приезжают. Кроме того, чтобы сравнить результаты среди различных социальных групп, анализируется взаимосвязь чистой миграции на основе резидентских (городских и сельских) и возрастных категорий с экономическими показателями. Выдвигается гипотеза, что на чистую миграцию из Казахстана в Россию сильно влияет экономическая ситуация в Казахстане, особенно уровень безработицы в Казахстане. Таким образом, результаты показывают, что городские жители в большей степени склонны переезжать в Россию, чем сельские жители из-за экономической ситуации. Делается вывод, что экономические причины не имеют значения для пенсионеров. На основе результатов исследования, формулируются практические шаги для улучшения ситуации с миграцией, а именно диверсификация экономики Казахстана, инвестирование (малые и средние предприятия) и пересмотр политики занятости.

Ключевые слова: миграция, Казахстан, Российская Федерация, экономика.

JEL: F22

1 Жаксыбаева Нурльайым - магистр государственной политики, Центр развития торговой политики при Министерстве национальной экономики Казахстана. <E-mail: n.zhaksybayeva@gmail.com>; Нуржанова Салтанат - магистр государственной политики, Казахстан. <E-mail: saltanatnurzhanova.a@gmail.com>. 